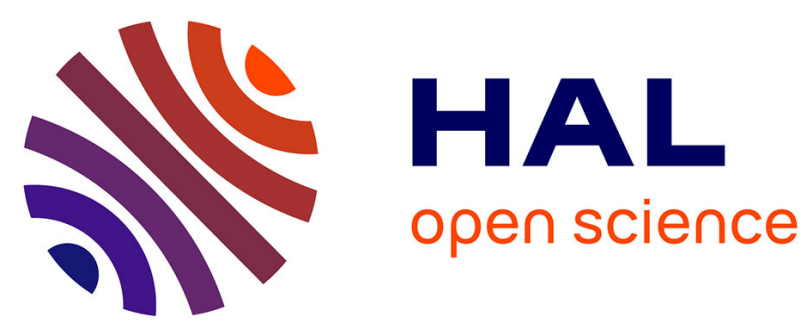

\title{
Cathepsin D: newly discovered functions of a long-standing aspartic protease in cancer and apoptosis.
} Emmanuelle El Liaudet-Coopman, Mélanie Beaujouin, Danielle Derocq, Marcel Garcia, Murielle Glondu-Lassis, Valérie Laurent-Matha, Christine Prébois, Henri Rochefort, Françoise Vignon

\section{To cite this version:}

Emmanuelle El Liaudet-Coopman, Mélanie Beaujouin, Danielle Derocq, Marcel Garcia, Murielle Glondu-Lassis, et al.. Cathepsin D: newly discovered functions of a long-standing aspartic protease in cancer and apoptosis.. Cancer Letters, 2006, 237 (2), pp.167-79. 10.1016/j.canlet.2005.06.007. inserm-00153729

\section{HAL Id: inserm-00153729 https://www.hal.inserm.fr/inserm-00153729}

Submitted on 11 Jun 2007

HAL is a multi-disciplinary open access archive for the deposit and dissemination of scientific research documents, whether they are published or not. The documents may come from teaching and research institutions in France or abroad, or from public or private research centers.
L'archive ouverte pluridisciplinaire HAL, est destinée au dépôt et à la diffusion de documents scientifiques de niveau recherche, publiés ou non, émanant des établissements d'enseignement et de recherche français ou étrangers, des laboratoires publics ou privés. 


\title{
Cathepsin D: newly discovered functions of a long-standing aspartic protease in cancer and apoptosis.
}

Emmanuelle Liaudet-Coopman*, Mélanie Beaujouin, Danielle Derocq, Marcel Garcia, Murielle Glondu-Lassis, Valérie Laurent-Matha, Christine Prébois, Henri Rochefort and Françoise Vignon.

INSERM U540 'Endocrinologie Moléculaire et Cellulaire des Cancers', Université de Montpellier 1, 60 rue de Navacelles, 34090 Montpellier, France.

*Corresponding author: E Liaudet-Coopman, INSERM U540, 60 rue de Navacelles, 34090 Montpellier, France; Tel [33] 4670430 80 ; FAX [33] 4675405 98, E-mail: liaudet@montp.inserm.fr

\begin{abstract}
The lysosomal aspartic protease cathepsin D (cath-D) is over-expressed and hyper-secreted by epithelial breast cancer cells. This protease is an independent marker of poor prognosis in breast cancer being correlated with the incidence of clinical metastasis. Cath-D overexpression stimulates tumorigenicity and metastasis. Indeed it plays an essential role in the multiple steps of tumor progression, in stimulating cancer cell proliferation, fibroblast outgrowth and angiogenesis, as well as in inhibiting tumor apoptosis. A mutated cath-D devoid of catalytic activity still proved mitogenic for cancer, endothelial and fibroblastic cells, suggesting an extra-cellular mode of action of cath-D involving a triggering, either directly or indirectly, of an as yet unidentified cell surface receptor.

Cath-D is also a key mediator of induced-apoptosis and its proteolytic activity has been involved generally in this event. During apoptosis, mature lysosomal cath-D is translocated to the cytosol. Since cath-D is one of the lysosomal enzymes which requires a more acidic $\mathrm{pH}$ to be proteolytically-active relative to the cysteine lysosomal enzymes, such as cath-B and -L, it is open to question whether cytosolic cath-D might be able to cleave substrate(s) implicated in the apoptotic cascade.
\end{abstract}

This review summarises our current knowledge on cath-D action in cancer progression and metastasis, as well as its dual function in apoptosis.

Keywords: cathepsin D, protease, cancer, metastasis, angiogenesis, apoptosis 


\section{Introduction}

Proteases of the cathepsin family are among the most studied lysosomal hydrolases that degrade proteins in lysosomes at an acidic $\mathrm{pH}$. Cathepsins can be divided into three subgroups according to their active-site amino acid (i.e., cysteine (B, C, H, F, K, L, O, S, V, W), aspartate (D and E) or serine (G) cathepsins [1].

Apart from their function in general protein turnover, knock-out experiments have revealed that cathepsins can also perform specific functions, such as neovascularization of endothelial progenitor cells [2], antigen presentation [3], cell growth and tissue homeostasis [4-7]. Interestingly, cathepsins also have crucial functions outside the lysosomal compartment (i.e., degradation of the extracellular matrix or induction of fibroblast invasive growth when secreted into the extracellular space and execution of programmed cell death when released into the cytosol [8-10]).

Several members of the cathepsins, in particular the aspartic protease cathepsin D (cathD) and the cysteine proteases cathepsin B and L, have been implicated in cancer progression and metastasis [8, 11-13]. More recently these cathepsins were shown to mediate the lysosomal cell death pathways [10].

The aim of the present review is to discuss the role of cath-D in cancer progression and metastasis, as well as its dual function in apoptosis.

\section{Cath-D: basic information}

Cath-D [E.C. 3.4.23.5] is an aspartic endo-protease that is ubiquitously distributed in lysosomes [14]. It was considered for a long time that the main function of cath-D was to degrade proteins in lysosomes at an acidic $\mathrm{pH}$. In addition to its classical role as a major protein-degrading enzyme in lysosomes and phagosomes, it has been shown that cath-D can also activate precursors of biologically active proteins in pre-lysosomal compartments of specialized cells [15].

Knock-out experiments of cath-D gene have shown that homozygous mice embryos developed normally. However, when pups were weaned, they began losing weight and rapidly died post-natally on day 26 [4]. Two major alterations were observed in the small intestine (necrosis and hemorrhage) and in the thymus (increased apoptosis), while the half life of bulk proteins was unchanged. This indicated that cath-D is required in certain epithelial cells for tissue remodelling and renewal, possibly by providing essential growth factors.

Acidic $\mathrm{pH}$ is required for the activity of cath-D in vitro with an optimum $\mathrm{pH}$ of 4.5-5.0 when tested using an extracellular matrix as substrate [16]. In contrast to other tissue proteases (e.g. serine proteases and metalloproteinases), no endogeneous cath-D tissue inhibitor is known in mammals. Pepstatin, a natural inhibitor of aspartic proteases isolated from various species of actinomycites [17] has often been used not only for affinity chromatography purification of cath-D but also to study its function in some in vitro systems.

Cath-D, like other aspartic proteases such as renin, chymosin, pepsinogen, has a bilobed organization. Crystal structures of native and pepstatin-inhibited forms of the mature human cath-D [18-20] revealed a high degree of tertiary structural similarity with other members of the aspartic protease family (e.g. pepsinogen and human immunodeficiency virus protease). No high-resolution structure has been reported for pro-cath-D.

\section{Maturation of cath-D}

Mechanisms associated with the processing and activation of lysosomal proteases remain largely unknown [21]. In general, three types of mechanism have been reported on for the processing and activation of aspartic proteases. The first, complete auto-activation, has been described for porcine pepsinogen [22]. The second is represented by fully-assisted activation of pro-renin [23]. Whilst the third proposed for cath-D is a combination of partial 
auto-activation and enzyme-assisted activation yielding mature enzyme [24-26]. By the use of a catalytically-inactive ${ }^{\mathrm{D} 231 \mathrm{~N}}$ cath-D expressed in a cath-D-deficient cell line [9], we have recently shown that the mechanism of cath-D maturation was independent of its catalytic function and so implicate a fully-assisted processing similarly to that of pro-renin [LaurentMatha et al. - submitted].

Cath-D is synthesized on the rough endoplasmic reticulum (RER) as a pre-pro-enzyme that undergoes several proteolytic cleavages during biosynthesis to produce the mature form $[24,27,28]$. Following the initial co-translational removal of the signal peptide to yield procath-D, sugars are attached at two N-linked glycosylation sites and the pro-enzyme is transported to Golgi stacks. The $52 \mathrm{kDa}$ pro-cath-D then binds to mannose-6-phosphate (M6P) receptors and is targeted to lysosomes [29, 30] yielding an active intermediate $48 \mathrm{kDa}$ single-chain molecule. This main proteolytic activation event most likely depends on the action of cysteine lysosomal and/or aspartic proteases [31-33]. Human cath-D catalytic sites include two critical aspartic residues (amino acid 33 and 231) located on the $14 \mathrm{kDa}$ and 34 $\mathrm{kDa}$ chains, respectively [18]. Depending on the cell type, cath-D may also be targeted to lysosomes in a M6P-independent manner [33, 34]. The intermediate $48 \mathrm{kDa}$ single-chain species is then cleaved in lysosomes into a mature two-chain enzyme consisting of a light (14 $\mathrm{kDa})$ amino-terminal domain and a heavy $(34 \mathrm{kDa})$ carboxyl-terminal domain. It is proposed that this proteolytic cleavage is accomplished by cysteine proteases in dense lysosomes, since processing can be partially inhibited by leupeptin [35].

Recently, we have highlighted a requirement for both cath-B and cath-L, two lysosomal cysteine proteases widely implicated in carcinogenesis [36], for the processing of intermediate $48 \mathrm{kDa}$ to mature $34 \mathrm{kDa}$ cath-D [Laurent-Matha et al. - submitted]. Interestingly, increased amounts of intermediate and mature cath-D have been detected in the brains of cath-B/-L double-knockout mice [37] as well as accumulation of intermediate cath-D in cath-L-deficient A549 cells and in lung tissue extracts of cath-L (-/-) mice [38]. Our results together with the reports using cath-B/L and cath-L knock-out cells demonstrate the involvement of cath-B and -L in cath-D processing.

Accompanying the conversion to the two-chain species, 7 amino acid residues between light and heavy chains are removed [39]. Furthermore, several more amino acids are also removed from the carboxyl terminus of heavy chains [40].

Pro-cath-D over-expressed by cancer cells is also secreted in excess and can be endocytosed by both cancer cells and by fibroblasts via M6P-receptors and other as yet unknown receptor(s) $[9,41]$. The RAP binding chain of the LDL receptor-related protein has been excluded as being an alternative receptor for cath-D endocytosis [42].

Endocytosed pro-cath-D undergoes maturation successively into $48 \mathrm{kDa}$ intermediate and $34+14 \mathrm{kDa}$ mature forms [41, 43]. Concerning the mechanisms of cath-D maturation following its endocytosis are concerned, nothing has so far been described [44]. We have shown that the processing of endocytosed pro-cath-D was also independent of its catalytic function and requires the cysteine proteases cath-B and cath-L, similarly to cellular cath-D originating from the RER [Laurent-Matha et al. - submitted].

In addition, secreted pro-cath-D, like pepsinogen, is capable of acid-dependent autoactivation in vitro [45], resulting in a catalytically active pseudo-cath-D, an enzyme species that retains 18 residues (27-44) of the pro-segment.

\section{Over-expression of cath-D in breast cancer cells.}

Studies in estrogen receptor positive breast cancer cell lines revealed that this housekeeping enzyme is highly regulated by estrogens and certain growth factors (i.e. IGF1, EGF) $[46,47]$. The mechanism of this over-expression does not seem to involve gene amplification or major chromosomal rearrangements [48]. In ER-positive breast cancer cell 
lines, both estrogen and growth factors stimulate cath-D protein and mRNA accumulation levels $[49,50]$. As far as other steroid responsive genes are concerned, the regulation of cathD mRNA accumulation by estrogen is mainly due to increased initiation of transcription [47]. Estrogen responsive elements have been defined in the proximal promoter region of the gene and in conjunction with other regulatory sequences (SP1, AP1) they may be responsible for the stimulation of cath-D gene expression [51].

\section{Cath-D as a prognostic factor in breast cancer.}

Different approaches, such as immuno-histochemistry, in situ hybridization, cytosolic immunoassay and Northern and Western blot analyses,s have indicated that in most breast cancer tumors, cath-D is over-expressed from 2- to 50-fold compared to its concentration in other cell types such as fibroblasts or normal mammary glands [52]. Several independent clinical studies have shown that the cath-D level in primary breast cancer cytosol is an independent prognostic parameter correlated with the incidence of clinical metastasis and shorter survival times [53, 54]. A meta-analysis of studies on node negative breast cancer [55], as well as a complete study on 2810 patients in Rotterdam [56] have confirmed the value of high concentrations of cath-D as a marker of aggressiveness.

The major cath-D producing cells appear to be cancer cells and stromal macrophages [57]. Cath-D production by fibroblasts appears variable according to various publications. Certain studies have indicated that cath-D production is low relative to cancer cells as shown by immunochemistry [57] and in situ hybridization with antisense RNA [58]. Other studies have indicated a prognostic role for cath-D over-expression by reactive stromal cells [59-62]. Pro-cath-D is also increased in the plasma of patients with metastatic breast cancer [63, 64], indicating that part of the pro-cath-D secreted by tumors can be released into the circulation.

\section{Role of cath-D in cancer progression and metastasis. \\ 6.1 Cath-D stimulates metastasis}

The direct role of cath-D in cancer metastasis was first demonstrated in rat tumor cells in which transfection-induced cath-D over-expression increased their metastatic potential in vivo $[65,66]$. In this rat tumor model, the cath-D mechanism responsible for metastasis stimulation seemed to have a positive effect on cell proliferation, favouring the growth of micrometastases, rather than increasing the invasive potential [65-69]. Using an RNA antisense strategy we showed that cath-D was a rate limiting factor in the outgrowth, tumorigenicity and lung colonization of MDA-MB-231 breast cancer cells [70].

\subsection{Cath-D as a mitogen for cancer cells.}

Several reports have indicated that cath-D stimulates cancer cell proliferation. Vignon and colleagues first showed that purified pro-cath-D from MCF-7 breast cancer cells stimulated MCF-7 cell growth [43]. Moreover, 3Y1-Ad12 rat cancer cells transfected with human cath-D cDNA grew more rapidly both at low or high cell densities in vitro and showed an increased experimental metastatic potential in vivo [65-67]. In addition, Vetvicka and colleagues reported that pro-cath-D was mitogenic for breast and prostate cancer cells [7173].

Different mechanisms have been proposed as responsible for the mitogenicity of cath-D. On the one hand, it has been proposed that its action as a ligand might involve either an interaction with the M6P moieties of cath-D with the M6P/IGF-2 receptor or even an interaction of a part of its pro-fragment (amino acids 27 to 44) with an unknown cell surface receptor [71, 74-76]. Alternatively, its catalytic activity in activating growth factors has been implicated [77, 78] or to prevent secretion of growth inhibitors [67]. The question remains as to whether secreted pro-cath-D could be activated extra-cellularly in a sufficiently acidic 
milieu. Indeed, the extracellular $\mathrm{pH}$ in tumors is generally more acidic that in corresponding normal tissues [79]. Recently we demonstrated that a mutated ${ }^{\mathrm{D} 231 \mathrm{~N}}$ cath-D devoid of proteolytic activity was still mitogenic both in vitro in three dimensional (3D) matrices and in vivo in athymic nude mice [11,68, 69]. These results therefore suggest that pro-cath-D may be acting as an extra-cellular binding protein and not as a protease by triggering either directly or indirectly an as yet unidentified cell surface receptor (Figure 1).

\subsection{Role of cath-D in angiogenesis.}

It is well established that tumor growth is dependent on angiogenesis [80]. Immunohistochemical studies have indicated that cath-D, independently of its proteolytic activity, stimulates not only cancer cell proliferation, but also tumor angiogenesis [69]. In this same study, we have demonstrated that human cath-D over-expressed by cancer cells significantly stimulated tumor angiogenesis in tumor xenografts in athymic mice.

Contrary to the case with other proteolytic enzymes, degradation of the extracellular matrix (ECM) did not seem to be implicated as a mechanism for cath-D [81], since catalytically-inactive ${ }^{\mathrm{D} 231 \mathrm{~N}}$ cath-D was as potent as wild-type cath-D in inducing angiogenesis [69].

The potential role of cath-D in angiogenesis has not yet been fully defined. An initial study suggested that cath-D might stimulate angiogenesis by releasing ECM-bound bFGF in breast cancer cells [77]. Moreover, a clinical study on 102 invasive breast carcinomas revealed a statistically significant association between cath-D expression and higher vessel counts [82]. However, it has also been reported that pro-cath-D secreted by prostate carcinoma cells might be responsible for the generation of angiostatin, which is a specific inhibitor of angiogenesis in vivo [83]. More recently, cath-D was also reported to cleave human prolactin, generating multiple 16K-like N-terminal prolactin fragments with antiangiogenic properties [84].

On the basis of our observations [69], we speculate that cath-D may stimulate endothelial cell growth via a paracrine loop, acting as a protein ligand, and either directly or indirectly triggering an as yet unidentified cell surface receptor - that could be present on both cancer cells, as previously suggested [68] and on endothelial cells (Figure 1).

\subsection{Paracrine action of cath-D on fibroblasts.}

\subsubsection{Stromal cells play a determinant role in cancer pathogenesis.}

Interaction between stromal cells and epithelial cells appears to be important for both normal development and neoplasis [85]. The identification of genes that are selectively expressed in the stroma of malignant lesions has provided new insight into the molecular basis of stromal-epithelial interactions. Stromally expressed genes include growth factors, proteases and extracellular matrix proteins, all biological activities with potential roles in malignant progression [86]. Stromal and tumor cells interchange numerous growth factors and proteases to activate the adjacent extracellular matrix and, in turn, induce the selection and expansion of neoplastic cells [86]. The fibroblast is a major cell type of the stromal compartment and, as such, is intimately involved in orchestrating the stromal part of the dialogue in tissue homeostasis [87]. The modification of fibroblasts in the stroma immediately adjacent to transformed epithelial cells has been documented in several tumor systems [8890].

\subsubsection{Stroma and cancer cells can interchange proteases.}

There is a lot of evidence that extracellular matrix, depending on its context, can actively regulate cellular processes such as growth, death, adhesion, migration, invasion, gene expression and differentiation [91-93]. Each cell type displays surface receptors appropriate 
for its tissue environment and interaction of these receptors with extracellular matrix components influence cell shape, behaviour and the response to soluble molecules including cytokines and growth factors [94]. During the transition from normal tissue to in situ and invasive carcinoma, the micro-environment of the local host stroma is an active player. In fact, stroma and tumor cells can interchange growth factors and also proteases, for example, matrix metalloproteases (MMPs) and urokinase plasminogen activator (uPA), to activate the adjacent extracellular matrix and, in turn, induce the selection and expansion of neoplastic cells [86]. Increased stromal growth accounts for most of the increase in breast volume in the post-puberbal years and also occurs in breast cancer.

\subsubsection{Cath-D promotes fibroblast outgrowth in 3D matrices.}

Cath-D, described as being localized to the surface of breast fibroblasts [95], might well be a mitogen that induces stromal proliferation. Indeed, we recently demonstrated a requirement of cath-D for fibroblast invasive growth using a $3 \mathrm{D}$ co-culture assay with cancer cells either secreting or not secreting pro-cath-D [9]. Ectopic expression of cath-D in cath-Ddeficient fibroblasts stimulated 3D outgrowth and was associated with a significant increase in fibroblast proliferation, survival, motility and invasive capacity, as well as by activation of the ras-MAP kinase pathway [9]. Interestingly, all these stimulatory effects on fibroblasts were independent of cath-D proteolytic activity [9].

The question remains, however, as to how cath-D induces such a major change in fibroblast phenotype. Since fibroblasts can become activated by either catalytically-active or inactive cath-D or indeed by the secreted pro-cath-D precursor, its proteolytic activity is clearly not directly involved in the stimulatory effect [9]. At present, the only receptor known to interact with the secreted pro-cath-D is M6P/IGF2 receptor, which has a well defined function in the transport of various ligands via the endosomal pathway [44]. However, the ability of this receptor to stimulate cellular responses via signaling pathways remains controversial although a recent study indicates that it may transduce IGF2 mitogenic activity via the MAP kinase pathway [96].

Another possibility is that secreted pro-cath-D binds to an as yet unidentified cell surface receptor coupled to the MAP kinase transduction pathway. Indeed it has been proposed that such a receptor exists at the cell surface of cancer and endothelial cells to mediate cath-D mitogenic activity $[41,68,69,71]$.

We therefore propose that cath-D may favor tumor progression not only by affecting the epithelial compartment, but also by promoting fibroblast outgrowth via a paracrine loop (Figure 1). Under these circumstances, cath-D over-expressed and hyper-secreted by cancer cells may be captured in vivo by stromal cells, may promote proliferation and survival, may stimulate motility and invasion of fibroblasts and consequently may enhance tumor-host homeostasis.

\subsubsection{Cath-D hyper-secreted by breast cancer cells is captured by fibroblasts.}

In addition to the degradation of the extracellular matrices, an increased stromal growth has also been described as occurring in tumors [90]. Tumor fibroblasts confer both morphogenic and mitogenic induction of epithelial cells and further enhancement of growth and progression requires active angiogenesis [90]. Therefore the factors required for the normal behaviour of fibroblasts are crucial. If these factors are over-expressed by cancer cells and can be captured by fibroblasts, then they might optimize the behaviour of fibroblasts thereby enhancing tumor development and progression.

Pro-cath-D secreted by breast cancer cells can be captured by fibroblasts [9, 41, 97]. According to these reports and to our previous report indicating a stimulatory effect of cath-D on tumor angiogenesis [69], cath-D over-expressed and hyper-secreted by breast cancer cells 
might be a mitogen that induces stromal proliferation in tumors. Moreover, stromal fibroblasts contribute extensively to the serine protease and MMP activities in tumors [88, 98, 99]. We were unable to detect any significant change in the mRNA expression of UPA, PAI1, MMP2, MMP9, MMP14, TIMP-1 and TIMP-2 in cath-D transfected fibroblasts [9]. However, cath-D may, by stimulating the growth of fibroblasts, indirectly increase the level of the other proteases implicated in the degradation of the extracellular matrix.

Conversely, the ability of extracellular matrix components to mediate expression of proteases has not yet been fully examined. Indeed, it has been shown that interaction of human breast fibroblasts with collagen I increased the secretion of pro-cath-B, but not that of pro-cath-D [95].

\subsection{Action of secreted cath-D as a binding protein.}

Initially, it was believed that the major role of proteases in metastasis was to facilitate the invasion of cancer cells by digesting the extra-cellular matrix and the basement membrane components [100]. Other evidence though suggests that proteases are also key regulators of tumor growth at both the primary and metastatic sites [101]. Moreover, it is generally assumed that the mechanism of mitogenic activity of proteases is due to their proteolytic activities facilitating either growth factor release [78], or growth inhibitor deterioration [67], or proteolytic activation of a mitogenic receptor, as shown for the thrombin receptor [102]. Like proteases acting at a neutral $\mathrm{pH}$, such as the plasminogen activator and the matrix metalloproteases, the precursors of lysosomal proteases (e.g. pro-cath- $\mathrm{B}, \mathrm{D}$, and $\mathrm{L}$ ) are also over-expressed and hyper-secreted by carcinoma cells [8, 103, 104].

Hyper-secreted cath-D might act either as a protease after its extracellular activation at an acidic $\mathrm{pH}$ or as a binding protein and its action could take place extracellularly as suggested by the high hyper-secretion of this pro-enzyme or intracellularly following its endocytosis via membrane receptors [11]. Degradation of the basement membrane after secretion and extracellular activation is unlikely to be the major mechanism for cath-D action, in contrast to neutral proteases, since cath-D activation requires an acidic $\mathrm{pH}$ which is found intra-cellularly in endosomes, lysosomes or phagosomes. At present, it is difficult to exclude any of these mechanisms, but our recent results strongly favour the hypothesis of cath-D acting as a secreted binding protein. Indeed, we reported that ${ }^{\mathrm{D} 231 \mathrm{~N}}$ cath-D mutated in its catalytic site and hence devoid of proteolytic activity, was still mitogenic for cancer, endothelial and fibroblastic cells, possibly by interacting with an unknown membrane receptor [9, 68, 69] (Figure 1). Moreover, according to the Fusek and Vetvicka model, procath-D may act as a ligand by triggering a trans-membrane receptor via its pro-peptide [71, 74-76]. Another mechanism by which cath-D could be mitogenic on cancer cells, without activation at neutral $\mathrm{pH}$, is by competing with IGFII on the M6P/IGFII receptor resulting in an activation of the IGFI receptor [105].

These mechanisms though are not mutually exclusive and, according to the conditions observed locally in vivo in the tumor (particularly $\mathrm{pH}$ and oxygenation), the importance of one mechanism or the other could vary. Cath-D, contrary to other proteases, therefore seems to be more of a mitogen than a protease, allowing cancer cells to cross the basement membrane and invade connective tissue or enter the blood stream.

\section{Complex role of cath-D in apoptosis.}

\subsection{Physiologic and pathologic role of cath-D in apoptosis.}

The function of cath-D in apoptosis is not yet fully understood and needs further investigation. Cath-D can either prevent apoptosis, as described under physiological conditions with cath-D knock-out mice experiments [4-7], or can promote apoptosis induced by cytotoxic agents [106-114]. This duality in the role of cath-D in apoptosis is also 
highlighted by our apparently conflicting results obtained with transfected 3Y1-Ad12 cell lines. Indeed, we previously published that over-expressed cath-D was preventing tumor apoptosis in a manner dependent on its catalytic function in cath-D transfected 3Y1-Ad12 xenografts [69]. Intriguingly, our recent study performed with the same cell lines, but this time treated with chemotherapeutic agents indicates a stimulation of apoptosis independently of cath-D catalytic activity [Beaujouin et al. - submitted]. It seems, therefore, that depending on the environmental conditions, cath-D may either inhibit or promote apoptosis via different mechanisms. This raises the interesting possibility that this protease is implicated as being involved in more than one apoptotic pathway.

\subsection{Cath-D is a key mediator of induced-apoptosis in cancer cells.}

Cath-D has been discovered as a key mediator of apoptosis induced by many apoptotic agents [10], such as IFN-gamma, FAS/APO, TNF-alpha [106], oxidative stress [108-112], adriamycin and etoposide [107, 114], cisplatin and 5-fluorouracil [114] as well as staurosporine [113]. The role of cath-D in apoptosis has been linked to the lysosomal release of mature $34 \mathrm{kDa}$ cath-D into the cytosol, leading in turn to the mitochondrial release of cytochrome c (cyt c) into the cytosol [108-111, 113, 115], activation of pro-caspases -9 and -3 $[109,113,115,116]$, in vitro cleavage of Bid at pH 6.2 [116], or Bax activation independently of Bid cleavage [117] (Figure 2). Numerous studies have shown that pepstatin A, an aspartic protease inhibitor, could partially delay apoptosis induced by IFN-gamma and FAS/APO [106], staurosporine [113, 117, 118], TNF-alpha [106, 116, 119], serum deprivation [120], oxidative stress [109-112] or even when pepstatin A was co-micro-injected with cath-D [115]. These authors have therefore concluded that cath-D plays a key role in apoptosis mediated via its catalytic activity.

However, cath- $\mathrm{D}$ is one of the lysosomal enzymes which require a more acidic $\mathrm{pH}$ to be proteolytically active relative to the cysteine lysosomal enzymes such as cath-B and -L. Acidification of the cytosol down to $\mathrm{pH}$ values of about 6.7-7 is a well-documented phenomenon in apoptosis $[121,122]$. However, cath-D can cleave its substrates up to a $\mathrm{pH}$ of 6.2 in vitro, but not above that level [123]. Hence, it is predictable that the proteolytic activity of cytosolic cath-D would be drastically impaired under adverse $\mathrm{pH}$ conditions, unfavourable for its catalytic function. It therefore remains open to question as to whether cath-D might be able to cleave cytosolic substrate(s) implicated in the apoptotic cascade. In accordance with this proposition, it has recently been shown that pepstatin A did not prevent the death of cells treated by either etoposide, doxorubicin, TNF-alpha or anti-CD95 [114, 119, 124]. Furthermore, pepstatin A did not suppress Bid cleavage or pro-caspases- 9 and -3 activation by photodynamic therapy in murine hepatoma cells [125]. Finally, a deficiency in cath-D activity did not alter cell death induction in CONCL fibroblasts [124].

\section{Conclusion.}

Cath-D is not only a mitogen for cancer cells but appears to be also a crucial paracrine factor for endothelial and fibroblastic cells. Its action in cancer seems to implicate its extracellular interaction with a cell surface membrane receptor. This receptor has not yet been identified, but it is clearly of considerable potential interest to clarify the mechanisms involved and to consider their medical applications. Cath-D evidently plays a dual role in apoptosis. In such physiological and pathological conditions as cancer this protease prevents apoptosis, whereas it is also established as a key positive mediator of induced-apoptosis.

\section{Acknowledgements}

This review was written in the memories of Dr Françoise Vignon who was a pioneer in cath$\mathrm{D}$ field and largely contributed to the studies on cath-D. 
This work was supported by the "Institut National de la Santé et de la Recherche Médicale" and the University of Montpellier I.

\section{Legend to figures}

\section{Figure 1. Role of cath-D in cancer progression.}

Pro-cath-D over-secreted by epithelial breast cancer cells is a mitogen for cancer cells acting as an extra-cellular binding protein possibly by triggering either directly or indirectly an as yet unidentified cell surface receptor. Cath-D may also favor tumor progression, not only by affecting the epithelial compartment but also by promoting fibroblast outgrowth via a paracrine loop involving interaction with an unknown cell surface receptor. Under these circumstances, pro-cath-D over-expressed and hyper-secreted by cancer cells is captured in vivo by stromal cells and may not only promote proliferation and survival, but also stimulate motility and invasion of fibroblasts, and consequently enhance tumor-host homeostasis. Procath-D secreted by cancer cells may stimulate angiogenesis, acting via a paracrine loop as a protein ligand by either directly or indirectly triggering an as yet unidentified cell surface receptor, which could be present both on cancer, fibroblastic and endothelial cells.

\section{Figure 2. Role of cath-D in apoptosis induction.}

Upon induction of apoptosis, lysosomal mature $34 \mathrm{kDa}$ cath-D is rapidly released from the lysosomes into the cytosol, leading in turn to the mitochondrial release of cytochrome c (cyt c) into the cytosol and caspase-9 activation after binding to Apaf-1 (apoptosis proteaseactivating factor) and caspase-3 activation [1]. The mechanism(s) of how cath-D mediates apoptosis remain(s) unknown. A possible mode of cath-D action may be the truncation of Bid into tBid in the cytosol. tBid may induce formation of the active Bax conformation in the cytosol by direct $\mathrm{tBid} / \mathrm{bax}$ interaction, allowing Bax insertion in the outer mitochondrial membrane and subsequent release of cyt c [1]. Alternatively, cath-D may also be required, via Bid-independent pathways, for the Bax-mediated release of AIF (Apoptosis Inducing Factor) from mitochondria into the cytoplasm and the nucleus, which in turn causes chromatin remodelling and early commitment to caspase-independent apoptosis [2].

\section{References}

[1] C. de Duve, Lysosomes revisited, Eur. J. Biochem. 137 (1983) 391-397. Review.

[2] C. Urbich, C. Heeschen, A. Aicher, K. Sasaki, T. Bruhl, M.R. Farhadi, P. Vajkoczy, W.K. Hofmann, C. Peters, L.A. Pennacchio, N.D. Abolmaali, E. Chavakis, T. Reinheckel, A.M. Zeiher, S. Dimmeler, Cathepsin L is required for endothelial progenitor cell-induced neovascularization, Nat. Med. 11 (2005) 206-213.

[3] T. Nakagawa, W. Roth, P. Wong, A. Nelson, A. Farr, J. Deussing, J.A. Villadangos, H. Ploegh, C. Peters, A.Y. Rudensky, Cathepsin L: critical role in Ii degradation and CD4 T cell selection in the thymus, Science 280 (1998) 450-453.

[4] P. Saftig, M. Hetman, W. Schmahl, K. Weber, L. Heine, H. Mossmann, A. Koster , B. Hess, M. Evers, K. von Figura et al., Mice deficient for the lysosomal proteinase cathepsin D exhibit progressive atrophy of the intestinal mucosa and profound destruction of lymphoid cells, EMBO J. 14 (1995) 3599-3608.

[5] M. Koike, H. Nakanishi, P. Saftig, J. Ezaki, K. Isahara, Y. Ohsawa, W. Schulz-Schaeffer, T. Watanabe, S. Waguri, S. Kametaka, M. Shibata, K. Yamamoto, E. Kominami, C. Peters, K. von Figura, Y. Uchiyama, Cathepsin D deficiency induces lysosomal storage with ceroid lipofuscin in mouse CNS neurons, J. Neurosci. 20 (2000) 6898-6906. 
[6] H. Nakanishi, J. Zhang, M. Koike, T. Nishioku, Y. Okamoto, E. Kominami, K. von Figura, C. Peters, K. Yamamoto, P. Saftig, and Y. Uchiyama, Involvement of nitric oxide released from microglia-macrophages in pathological changes of cathepsin D-deficient mice, J. Neurosci. 21 (2001) 7526-7533.

[7] M. Koike, M. Shibata, Y. Ohsawa, H. Nakanishi, T. Koga, S. Kametaka, S. Waguri, T. Momoi, E. Kominami, C. Peters, K. von Figura, P. Saftig, and Y. Uchiyama, Involvement of two different cell death pathways in retinal atrophy of cathepsin D-deficient mice, Mol. Cell. Neurosci. 22 (2003) 146-161.

[8] J.E. Koblinski, M. Ahram, B.F. Sloane, Unraveling the role of proteases in cancer. Clin. Chim. Acta. 291 (2000) 113-135. Review.

[9] V. Laurent-Matha, S. Maruani-Herrmann, C. Prébois, M. Beaujouin, M. Glondu, A. Noël, M.L. Alvarez-Gonzalez, S. Blacher, P. Coopman, S. Baghdiguian, C. Gilles, J. Loncarek, G. Freiss, F. Vignon, and E. Liaudet-Coopman, Catalytically-inactive human cathepsin D triggers fibroblast invasive growth, J. Cell Biol. 168 (2005) 489-499.

[10] N. Fehrenbacher, M. Jaattela, Lysosomes as targets for cancer therapy, Cancer Res. 65 (2005) 2993-2995.

[11] H. Rochefort, and E. Liaudet-Coopman, Cathepsin D in cancer metastasis: a protease and a ligand, APMIS 107 (1999) 86-95.

[12] V. Turk, J. Kos, B. Turk, Cysteine cathepsins (proteases)--on the main stage of cancer? Cancer Cell. 5 (2004) 409-410.

[13] J.A. Joyce, A. Baruch, K. Chehade, N. Meyer-Morse, E. Giraudo, F.Y. Tsai, D.C. Greenbaum, J.H. Hager, M. Bogyo, D. Hanahan, Cathepsin cysteine proteases are effectors of invasive growth and angiogenesis during multistage tumorigenesis, Cancer Cell. 5 (2004) 443-453.

[14] A.J. Barrett, Cathepsin D: Purification of isoenzymes from human and chicken liver, Biochem. J. 117 (1970) 601-607.

[15] S. Diment, K.J. Martin, P.D. Stahl, Cleavage of parathyroid hormone in macrophage endosomes illustrates a novel pathway for intracellular processing of proteins, J. Biol. Chem. 264 (1989) 13403-13406.

[16] P. Briozzo, M. Morisset, F. Capony, C. Rougeot, H. Rochefort, In vitro degradation of extracellular matrix with Mr 52,000 cathepsin D secreted by breast cancer cells, Cancer Res. 48 (1988) 3688-3692.

[17] H. Umezawa, T. Aoyagi, H. Morishima, M. Matsuzaki, M. Hamada, T. Takeuchi, Pepstatin, a new pepsin inhibitor produced by Actinomycetes, J. Antibiot. 23 (1970) 259-262.

[18] P. Metcalf, and M. Fusek, Two crystal structures for cathepsin D: the lysosomal targeting signal and active site, EMBO J. 12 (1993) 1293-1302.

[19] E.T. Baldwin, T.N. Bhat, S. Gulnik, M.V. Hosur, R.C. Sowder II, R.E. Cachau, J. Collins, A.M. Silva, J.W. Erickson, Crystal structures of native and inhibited forms of human cathepsin D: implications for lysosomal targeting and drug design, Proc. Natl. Acad. Sci. USA 90 (1993) 6796-6800.

[20] A.Y. Lee, S.V. Gulnik, J.W. Erickson, Conformational switching in an aspartic proteinase,

Nat. Struct. Biol. 5 (1998) 866-871.

[21] K. Ishidoh, and E. Kominami, Processing and activation of lysosomal proteinases, Biol. Chem. 383 (2002) 1827-1831. 
[22] J. Tang, R.N. Wong, Evolution in the structure and function of aspartic proteases, J. Cell. Biochem. 33 (1987) 53-63.

[23] W.A. Hsueh, and J.D. Baxter, Human prorenin, Hypertension 17 (1991) 469-477.

[24] G. Richo, and G.E. Conner, Proteolytic activation of human procathepsin D, Adv. Exp. Med. Biol. 306 (1991) 289-296.

[25] G.E. Conner, and G. Richo, Isolation and characterization of a stable activation intermediate of the lysosomal aspartyl protease cathepsin D, Biochem. 31 (1992) 1142-1147.

[26] L.B. Larsen, A. Boisen, and T.E. Petersen, Procathepsin D cannot autoactivate to cathepsin D at acid pH, FEBS Lett. 319 (1993) 54-58.

[27] A. Hasilik, and E.F. Neufeld, Biosynthesis of lysosomal enzymes in fibroblasts. Synthesis as precursors of higher molecular weight, J. Biol. Chem. 255 (1980) 4937-4945.

[28] G. Richo, and G.E. Conner, Structural requirements of procathepsin D activation and maturation, J. Biol. Chem. 269 (1994) 14806-14812.

[29] K. Von Figura and A. Hasilik, Lysosomal enzymes and their receptors, Annu. Rev. Biochem. 55 (1986) 167-193.

[30] S. Kornfeld, Lysosomal enzyme targeting, Biochem. Soc. Trans. 18 (1990) 367-374.

[31] M. Hentze, A. Hasilik, and K. von Figura, Enhanced degradation of cathepsin D synthesized in the presence of the threonine analog beta-hydroxynorvaline, Arch. Biochem. Biophys. 230 (1984) 375-382.

[32] A.M. Samarel, A.G. Ferguson, R.S. Decker, M. Lesch, Effects of cysteine protease inhibitors on rabbit cathepsin D maturation, Am. J. Physiol. 257 (1989) 1069-1079.

[33] S. Rijnboutt, A.J. Kal, H.J. Geuze, H. Aerts, G.J. Strous, Mannose 6-phosphateindependent targeting of cathepsin D to lysosomes in HepG2 cells, J. Biol. Chem. 266 (1991) 23586-23592.

[34] F. Capony, T. Braulke, C. Rougeot, S. Roux, P. Montcourrier, and H. Rochefort, Specific mannose-6-phosphate receptor-independent sorting of pro-cathepsin D in breast cancer cells, Exp. Cell Res. 215 (1994) 154-163.

[35] V. Gieselmann, A. Hasilik, and K. von Figura, Processing of human cathepsin D in lysosomes in vitro, J. Biol. Chem. 260 (1985) 3215-3220.

[36] M.J. Duffy, Proteases as prognostic markers in cancer, Clin. Cancer Res. 2 (1996) 613618.

[37] U. Felbor, B. Kessler, W. Mothes, H.H. Goebel, H.L. Ploegh, R.T. Bronson, and B.R. Olsen, Neuronal loss and brain atrophy in mice lacking cathepsins B and L, Proc. Natl. Acad. Sci. U.S.A. 99 (2002) 7883-7888.

[38] A. Wille, A. Gerber, A. Heimburg, A. Reisenauer, C. Peters, P. Saftig, T. Reinheckel, T. Welte, and F. Buhling, Cathepsin L is involved in cathepsin D processing and regulation of apoptosis in A549 human lung epithelial cells, Biol. Chem. 385 (2004) 665-670.

[39] T. Kobayashi, K. Honke, S. Gasa, T. Fujii, S. Maguchi, T. Miyazaki, A. and Makita, Proteolytic processing sites producing the mature form of human cathepsin D, Int. J. Biochem. 24 (1992) 1487-1491.

[40] A.H. Erickson, and G. Blobel, Carboxyl-terminal proteolytic processing during biosynthesis of the lysosomal enzymes beta-glucuronidase and cathepsin D, Biochem. 22 (1983) 5201-5205. 
[41] V. Laurent-Matha, M.R. Farnoud, A. Lucas, C. Rougeot, M. Garcia, and H. Rochefort, Endocytosis of pro-cathepsin D into breast cancer cells is mostly independent of mannose-6phosphate receptors, J. Cell. Sci. 111 (1998) 2539-2549.

[42] V. Laurent-Matha, A. Lucas, S. Huttler, K. Sandhoff, M. Garcia, H. Rochefort, Procathepsin D interacts with prosaposin in cancer cells but its internalization is not mediated by LDL receptor-related protein, Exp. Cell. Res. 277 (2002) 210-219.

[43] F. Vignon, F. Capony, M. Chambon, G. Freiss, M. Garcia, and H. Rochefort, Autocrine growth stimulation of the MCF 7 breast cancer cells by the estrogen-regulated $52 \mathrm{~K}$ protein, Endocrinology 118 (1986) 1537-1545.

[44] M.J. Clague, Molecular aspects of the endocytic pathway, Biochem. J. 336 (1998) 271282.

[45] A. Hasilik, K. von Figura, E. Conzelmann, H. Nehrkorn, and K. Sandhoff, Lysosomal enzyme precursors in human fibroblasts. Activation of cathepsin D precursor in vitro and activity of beta-hexosaminidase A precursor towards ganglioside GM2, Eur. J. Biochem. 125 (1982) 317-321.

[46] H. Rochefort, V. Cavaillès, P. Augereau, F. Capony, T. Maudelonde, I. Touitou, M. Garcia, Overexpression and hormonal regulation of pro-cathepsin D in mammary and endometrial cancer, J. Steroid Biochem. 34 (1989) 177-182.

[47] V. Cavaillès, P. Augereau, H. Rochefort, Cathepsin D gene is controlled by a mixed promoter and estrogens stimulate only TATA dependent transcription in breast cancer cells, Proc. Natl. Acad. Sci. USA 90 (1993) 203-207.

[48] P. Augereau, M. Garcia, M.G. Mattei, V. Cavaillès, F. Depadova, D. Derocq, F. Capony, P. Ferrara, H. Rochefort, Cloning and sequencing of the 52K cathepsin D cDNA of MCF7 breast cancer cells and mapping on chromosome 11, Mol. Endo. 2 (1988) 186-192.

[49] B.R. Westley, F.E. May, Oestrogen regulates cathepsin D mRNA levels in oestrogen responsive human breast cancer cells, Nucl. Acids. Res. 15 (1987) 3773-3786.

[50] V. Cavaillès, M. Garcia, H. Rochefort, Regulation of cathepsin D and pS2 gene expression by growth factors in MCF7 human breast cancer cells, Mol. Endocrinol. 3 (1989) 552-558.

[51] P. Augereau, F. Mirallès, V. Cavaillès, C. Gaudelet, M. Parker, H. Rochefort, Characterization of the proximal estrogen responsive element of human cathepsin D gene, Mol. Endocrinol. 8 (1994) 693-703.

[52] F. Capony, C. Rougeot, P. Montcourrier, V. Cavaillès, G. Salazar, H. Rochefort, Increased secretion, altered processing, and glycosylation of pro-cathepsin D in human mammary cancer cells, Cancer Res. 49 (1989) 3904-3909.

[53] H. Rochefort, Cathepsin D in breast cancer: a tissue marker associated with metastasis, Eur. J. Cancer 28A (1992) 1780-1783.

[54] B.R. Westley, and F.E. May, Prognostic value of cathepsin D in breast cancer, Br. J. Cancer 79 (1999) 189-190.

[55] G. Ferrandina, G. Scambia, F. Bardelli, B. Panici, S. Mancuso, A. Messori, Relationship between cathepsin-D content and disease-free survival in node-negative breast cancer patients: a meta-analysis, Br. J. Cancer 76 (1997) 661-666.

[56] J.A. Foekens, M.P. Look, J. Bolt-de Vries, M. Meijer-van Gelder, W.L.J. van Putten, J.G.M. Klijn, Cathepsin D in primary breast cancer : prognostic evaluation involving 2810 patients, Br. J. Cancer 79 (1999) 300-307. 
[57] P. Roger, P. Montcourrier, T. Maudelonde, J.P. Brouillet, A. Pagès, F. Laffargue, H. Rochefort, Cathepsin D immunostaining in paraffin-embedded breast cancer cells and macrophages. Correlation with cytosolic assay, Human Path. 25 (1994) 863-871.

[58] C. Escot, Y. Zhao, C. Puech, and H. Rochefort, Cellular localisation by in situ hybridisation of cathepsin $\mathrm{D}$, stromelysin 3, and urokinase plasminogen activator RNAs in breast cancer, Breast Cancer Res. Treat. 38 (1996) 217-226.

[59] H. Joensuu, S. Toikkanen, and J. Isola, Stromal cell cathepsin D expression and longterm survival in breast cancer, Br. J. Cancer 71 (1995) 155-159.

[60] M. Nadji, M. Fresno, M. Nassiri, G. Conner, A. Herrero, and A.R. Morales, Cathepsin D in host stromal cells, but not in tumor cells, is associated with aggressive behavior in nodenegative breast cancer, Hum. Pathol. 27 (1996) 890-895.

[61] A.E. O'Donoghue, D.N. Poller, J.A. Bell, M.H. Galea, C.W. Elston, R.W. Blamey, I.O.Ellis, Cathepsin D in primary breast carcinoma: adverse prognosis is associated with expression of cathepsin D in stromal cells, Breast Cancer Res. Treat. 33 (1995) 137-145.

[62] B. Têtu, J. Brisson, H. Lapointe, C.S. Wang, P. Bernard, and C. Blanchette, Cathepsin D expression by cancer and stromal cells in breast cancer: an immunohistochemical study of 1348 cases, Breast Cancer Res. Treat. 55 (1999) 137-147.

[63] J.P. Brouillet, F. Dufour, G. Lemamy, M. Garcia, N. Schlup, J. Grenier, J.C. Mani, H. Rochefort, Increased cathepsin D level in serum of patients with metastatic breast carcinoma detected with a specific pro-cathepsin D immunoassay, Cancer 79 (1997) 2132-2136.

[64] D.E. Jarosz, P.J. Hamer, D.Y. Tenney, J.R. Zabrecky, Elevated levels of pro-cathepsin D in the plasma of breast cancer patients, Int. J. Oncol. 6 (1995) 859-865.

[65] M. Garcia, D. Derocq, P. Pujol, and H. Rochefort, Overexpression of transfected cathepsin D in transformed cells increases their malignant phenotype and metastatic potency, Oncogene 5 (1990) 1809-1814.

[66] E. Liaudet, M. Garcia, and H. Rochefort, Cathepsin D maturation and its stimulatory effect on metastasis are prevented by addition of KDEL retention signal, Oncogene 9 (1994) $1145-1154$.

[67] E. Liaudet, D. Derocq, H. Rochefort, and M. Garcia. Transfected cathepsin D stimulates high density cancer cell growth by inactivating secreted growth inhibitors, Cell Growth Differ. 6 (1995) 1045-1052.

[68] M. Glondu, P. Coopman, V. Laurent-Matha, M. Garcia, H. Rochefort, and E. LiaudetCoopman, A mutated cathepsin-D devoid of its catalytic activity stimulates the growth of cancer cells, Oncogene 20 (2001) 6920-6929.

[69] G.J. Berchem, M. Glondu, M. Gleizes, J.P. Brouillet, M. Garcia, E. Liaudet-Coopman, Cathepsin-D affects multiple steps of tumor progression: Proliferation, angiogenesis and apoptosis, Oncogene 51 (2002) 5951-5955.

[70] M. Glondu, E. Liaudet-Coopman, D. Derocq, N. Platet, H. Rochefort, and M. Garcia, Down-regulation of cathepsin-D by antisense gene transfer inhibits tumor growth and metastatic potential of human breast cancer cells, Oncogene 21 (2002) 5127-5134.

[71] M. Fusek, V. Vetvicka, Mitogenic function of human procathepsin D: the role of the propeptide, Biochem. J. 303 (1994) 775-780.

[72] V. Vetvicka, J. Vektvickova, and M. Fusek, Effect of human cathepsin D on proliferation of human cell lines, Cancer Letters 79 (1994) 131-135. 
[73] V. Vetvicka, J. Vetvickova, M. Fusek, Effect of procathepsin D and its activation peptide on prostate cancer cells, Cancer Lett. 129 (1998) 55-59.

[74] V. Vetvicka, J. Vetvickova, I. Hilgert, Z. Voburka, M. Fusek, Analysis of the interaction of procathepsin D activation peptide with breast cancer cells, Int. J. Cancer 73 (1997) 403409.

[75] V. Vetvicka, J. Vetvickova, M. Fusek, Anti-human procathepsin D activation peptide antibodies inhibit breast cancer development, Breast Cancer Res. Treat. 57 (1999) 261-269.

[76] V. Vetvicka, J. Vetvickova, M. Fusek, Role of procathepsin D activation peptide in prostate cancer growth, Prostate 44 (2000) 1-7.

[77] P. Briozzo, J. Badet, F. Capony, I. Pieri, P. Montcourrier, D. Barritault, H. Rochefort, MCF7 mammary cancer cells respond to bFGF and internalize it following its release from extracellular matrix: a permissive role of cathepsin D, Exp. Cell Res. 194 (1991) 252-259.

[78] D.B. Rifkin, Cross-talk among proteases and matrix in the control of growth factor action, Fibrinolysis \& Proteolysis 11 (1997) 3-9.

[79] J.R. Griffiths, Are cancer cells acidic?, Br. J. Cancer 64 (1991) 425-427.

[80] J. Folkman, Anti-angiogenesis: new concept for therapy of solid tumors, Ann. Sug. 175 (1972) 409-416.

[81] M.S. Pepper, Role of the matrix metalloproteinase and plasminogen activatorplasminsystems in angiogenesis, Arterioscler. Thromb. Vasc. Biol. 21 (2001) 1104-1117.

[82] M.C. Gonzalez-Vela, M.F. Garijo, F. Fernandez, L. Buelta, J.F. Val-Bernal, Cathepsin-D in host stromal cells is associated with more highly vascular and aggressive invasive breast carcinoma, Histopathology 34 (1999) 35-42.

[83] W. Morikawa, K. Yamamoto, S. Ishikawa, S. Takemoto, M. Ono, J. Fukushi, S. Naito, C. Nozaki, S. Iwanaga and M. Kuwano, Angiostatin generation by cathepsin-D secreted by human prostate carcinoma cells, J. Biol. Chem. 275 (2000) 38912-38920.

[84] D. Piwnica, P. Touraine, I. Struman, S. Tabruyn, G. Bolbach, C. Clapp, J.A. Martial, P.A. Kelly, V. Goffin, Mol. Endocrinol. 18 (2004) 2522-2542.

[85] B. Elenbaas, and R.A. Weinberg, Heterotypic signaling between epithelial tumor cells and fibroblasts in carcinoma formation, Exp. Cell Res. 264 (2001) 169-184.

[86] L.A. Liotta, and E.C. Kohn, The microenvironment of the tumor-host interface, Nature 411 (2001) 375-379.

[87] F. Grinnell, Fibroblasts, myofibroblasts, and wound contraction, J. Cell Biol. 124 (1994) 401-404.

[88] P. Basset, J.P. Bellocq, C. Wolf, I. Stoll, P. Hutin, J.M. Limacher, O. Podhajcer, M.P. Chenard, M.C. Rio, P. Chambon, A novel metalloproteinase gene specifically expressed in stromal cells of breast carcinomas, Nature 348 (1990) 699-704.

[89] A.F. Olumi, G.D. Grossfeld, S.W. Hayward, P.R. Caroll, T.D. Tslty, and G.R. Cunha, Carcinoma-associated fibroblasts direct tumor progression of initiated human prostatic epithelium, Cancer Res. 59 (1999) 5002-5011.

[90] M.P. Shekhar, J. Werdell, S.J. Santner, R.J. Pauley, and L. Tait, Breast stroma plays a dominant regulatory role in breast epithelial growth and differentiation: implications for tumor development and progression, Cancer Res. 61 (2001) 1320-1326.

[91] D.E. Ingber, and J. Folkman, How does extracellular matrix control capillary morphogenesis? Cell 58 (1989) 803-805. 
[92] R.L. Juliano, and S. Haskill, Signal transduction from the extracellular matrix, J. Cell. Biol. 120 (1993) 577-585.

[93] R.K. Assoian, E.E. Marcantonio, The extracellular matrix as a cell cycle control element in atherosclerosis and restenosis, J. Clin. Invest. 98 (1996) 2436-2439.

[94] C.Q. Lin, and M.J. Bissell, Multi-faceted regulation of cell differentiation by extracellular matrix, FASEB J. 7 (1993) 737-743.

[95] J.E. Koblinski, J. Dosescu, M. Sameni, K. Moin, K. Clark, and B.F. Sloane, Interaction of human breast fibroblasts with collagen I increased secretion of procathepsin B, J. Biol. Chem. 277 (2002) 32220-32227.

[96] T. McKinnon, C. Chakraborty, L.M. Gleeson, P. Chidiac, and P.K. Lala, Stimulation of human extravillous trophoblast migration by IGF-II is mediated by IGF type 2 receptor involving inhibitory G protein(s) and phosphorylation of MAPK, J. Clin. Endocrinol. Metab. 86 (2001) 3665-3674.

[97] N. Heylen, L.M. Vincent, V. Devos, V. Dubois, C. Remacle, and A. Trouet, Fibroblasts capture cathepsin D secreted by breast cancer cells: possible role in the regulation of the invasive process, Int. J. Cancer 20 (2002) 761-767.

[98] J.A. Uria, M. Stahle-Backdahl, M. Seiki, A. Fueyo, and C. Lopez-Otin, Regulation of collagenase-3 expression in human breast carcinomas is mediated by stromal-epithelial cell interactions, Cancer Res. 57 (1997) 4882-4888.

[99] L. Christensen, A.C. Wiborg Simonsen, C.W. Heegaard, S.K. Moestrup, J.A. Andersen, P.A. Andreasen, Immunohistochemical localization of urokinase-type plasminogen activator, type-1 plasminogen-activator inhibitor, urokinase receptor and alpha(2)-macroglobulin receptor in human breast carcinomas, Int. J. Cancer 66 (1996) 441-452.

[100] L.A. Liotta, P.S. Steeg, W.G. Stetler-Stevenson, Cancer metastasis and angiogenesis: an imbalance of positive and negative regulation, Cell 64 (1991) 327-336.

[101] A.F. Chambers, L.M. Matrisian, Changing views of the role of matrix metalloproteinases in metastasis, J. Natl. Cancer Inst. 89 (1997) 1260-1270.

[102] D.H. Carney, D.D. Cunningham, Role of specific cell surface receptors in thrombinstimulated cell division, Cell 15 (1978) 1341-1349.

[103] H. Rochefort, F. Capony, M. Garcia, V. Cavaillès, G. Freiss, M. Chambon, M. Morisset, and F. Vignon, Estrogen-induced lysosomal proteases secreted by breast cancer cells: a role in carcinogenesis? J. Cell. Biochem. 35 (1987) 17-29.

[104] S.E. Kane, M.M. Gottesman, The role of cathepsin L in malignant transformation, Semin. Cancer Biol. 1 (1990) 127-136.

[105] M. Mathieu, H. Rochefort, B. Barenton, C. Prebois, F Vignon, Interactions of cathepsin-D and insulin-like growth factor-II (IGF-II) on the IGF-II/mannose-6-phosphate receptor in human breast cancer cells and possible consequences on mitogenic activity of IGF-II. Mol Endocrinol. 4 (1990) 1327-1335.

[106] L.P. Deiss, H. Galinka, H. Berissi, O. Cohen, Cathepsin D protease mediates programmed cell death induced by interferon gamma, Fas/APO-1 and TNF alpha, EMBO J. 15 (1996) 3861-3870.

[107] G.S. Wu, P. Saftig, C. Peters, W.S. El-Deiry, Potential role of cathepsin D in p53dependent tumor suppression and chemosensitivity, Oncogene 16 (1998) 2177-2183. 
[108] K. Roberg, K. Ollinger, Oxidative stress causes relocation of the lysosomal enzyme cathepsin D with ensuing apoptosis in neonatal rat cardiomyocytes, Am. J. Pathol. 152 (1998) 1151-1156.

[109] K. Ollinger, Inhibition of cathepsin D prevents free-radical-induced apoptosis in rat cardiomyocytes, Arch. Biochem. Biophys. 373 (2000) 346-351.

[110] K. Roberg, Relocalization of cathepsin D and cytochrome c early in apoptosis revealed by immunoelectron microscopy, Lab. Invest. 81 (2001) 149-158.

[111] K. Kagedal, U. Johansson, K. Öllinger, The lysosomal protease cathepsin D mediates apoptosis induced by oxidative stress, FASEB J. 15 (2001) 1592-1594.

[112] K. Takuma, M. Kiriu, K. Mori, E. Lee, R. Enomoto, A. Baba, T. Matsuda, Roles of cathepsins in reperfusion-induced apoptosis in cultured astrocytes, Neurochem. Int. 42 (2003) 153-159.

[113] A.C. Johansson, H. Steen, K. Öllinger, K. Roberg, Cathepsin D mediates cytochrome c release and caspase activation in human fibroblast apoptosis induced by staurosporine, Cell Death Differ. 10 (2003) 1253-1259.

[114] L. Emert-Sedlak, S. Shangary, A. Rabinovitz, M.B. Miranda, S.M. Delach, D.E. Johnson, Involment of cathepsin D in chemotherapy-induced cytochrome c release, caspase activation, and cell death, Mol. Cancer Ther. 4 (2005) 733-742.

[115] K. Roberg, K. Kagedal, K. Ollinger, Microinjection of cathepsin d induces caspasedependent apoptosis in fibroblasts, Am. J. Pathol. 161 (2002) 89-96.

[116] M. Heinrich, J. Neumeyer, M. Jakob, C. Hallas, V. Tchikov, S. Winoto-Morbach, M. Wickel, W. Schneider-Brachert, A. Trauzold, A. Hethke, S. Schutze, Cathepsin D links TNFinduced acid sphingomyelinase to Bid-mediated caspase-9 and -3 activation, Cell Death Differ. 11 (2004) 550-563.

[117] N. Bidère, H.K. Lorenzo, S. Carmona, M. Laforge, F. Harper, C. Dumont, A. Senik, Cathepsin D triggers Bax activation, resulting in selective apoptosis-inducing factor (AIF) relocation in T lymphocytes entering the early commitment phase to apoptosis, J. Biol. Chem. 278 (2003) 31401-31411.

[118] A. Terman, J. Neuzil, K. Kagedal, K. Ollinger, U.T. Brunk, Decreased apoptotic response of inclusion-cell disease fibroblasts: a consequence of lysosomal enzyme missorting? Exp. Cell Res. 274 (2002) 9-15.

[119] M. Demoz, R. Castino, P. Cesaro, F.M. Baccino, G. Bonelli, C. Isidoro, Endosomallysosomal proteolysis mediates death signalling by TNFalpha, not by etoposide, in L929 fibrosarcoma cells: evidence for an active role of cathepsin D, Biol. Chem. 383 (2002) 1237 1248 .

[120] M. Shibata, S. Kanamori, K. Isahara, Y. Ohsawa, A. Konishi, S. Kametaka, T. Watanabe, S. Ebisu, K. Ishido, E. Kominami, Y. Uchiyama, Participation of cathepsins B and $\mathrm{D}$ in apoptosis of PC12 cells following serum deprivation, Biochem. Biophys. Res. Commun. 251 (1998) 199-203.

[121] R.A. Gottlieb, J. Nordberg, E. Skowronski, B.M. Babior, Apoptosis induced in Jurkat cells by several agents is preceded by intracellular acidification, Proc. Natl. Acad. Sci. USA 93 (1996) 654-658.

[122] S. Matsuyama, J. Llopis, Q.L. Deveraux, R.Y. Tsien, J.C. Reed, Changes in intramitochondrial and cytosolic $\mathrm{pH}$ : early events that modulate caspase activation during apoptosis, Nat. Cell Biol. 2 (2000) 318-325. 
[123] F. Capony, M. Morisset, A.J. Barrett, J.P. Capony, P. Broquet, F. Vignon, M. Chambon, P. Louisot, H. Rochefort, Phosphorylation, glycosylation, and proteolytic activity of the 52kD estrogen-induced protein secreted by MCF7 cells, J. Cell Biol. 104 (1987) 253-262.

[124] C. Tardy, J. Tyynela, A. Hasilik, T. Levade, N. Andrieu-Abadie, Stress-induced apoptosis is impaired in cells with a lysosomal targeting defect but is not affected in cells synthesizing a catalytically inactive cathepsin D, Cell Death Differ. 10 (2003) 1090-1100.

[125] J.J. Jr Reiners, J.A. Caruso, P. Mathieu, B. Chelladurai, X.M. Yin, D. Kessel, Release of cytochrome $\mathrm{c}$ and activation of pro-caspase-9 following lysosomal photodamage involves Bid cleavage, Cell Death Differ. 9 (2002) 934-944. 